\title{
RECONSTRUCTION OF ANCIENT GREEK PAINTING IN THE CONTEXT OF MODERN DIGITAL TECHNOLOGIES
}

\author{
Petrushevskyi Andri' ${ }^{1}$, Petrushevska Natalia ${ }^{2}$ \\ ${ }^{1}$ Candidate of Technical Sciences, Associate Professor of the Department of Information Technologies \\ and Design, State University of Infrastructure and Technologies, Kyiv, Ukraine, \\ e-mail: zmodeller@gmail.com, orcid:0000-0002-4199-2179 \\ ${ }^{2}$ Kyiv, Ukraine, \\ e-mail: natalipetrushevski@gmail.com, orcid:0000-0001-5542-0174
}

\begin{abstract}
Explore the possibility of forming an algorithm that allows for the reconstruction of the lost compositions of easel painting by outstanding masters of the Ancient Wurld.

The purpose. Form an algorithm of the scheme of actions based onon the basis of the received historical information allowing to make the reconstruction of the lost compositions of easel painting of outstanding masters of Ancient Greece.

Methodology. In the study, the following research methods were used:

1) analytical method, by which the current literature had been analyzed;

2) theoretical and conceptual method, which made it possible to determine the conditions necessary for the implementation of IT-technology into cultural and artistic practice; The study used the methods of computer modeling and analysis, which made it possible to increase the accuracy of the results. The authors of the article consistently consider the algorithm of actions necessary to restore the lost works of the past. The work takes into account the technological features of the layer-by-layer painting of the Ancient World and analyzes the color scheme used by the masters of antiquity. For clarity, the authors have created a special scheme - a color square. The creation of this material was preceded by a deep study of ancient sources, in particular the works of Pliny the Elder.
\end{abstract}

Results. The main elements necessary for the restoration of the lost pictorial work of art have been established. The main reconstruction algorithm is stated: drawing, composition and methodology for creating a work of antique art. Hellenistic Greek colouristic is systematized according to the "Color square" scheme. All this information can be used in deep machine learning technologies according to certain algorithms and can give very interesting results.

The scientificance novelty. Consist in the creation of a scheme of actions aimed at restoring the image as close as possible to the lost original on the basis of the preserved literary and material artifacts.

Practical significance. This algorithm can be useful when creating computer software designed to recreate lost works of the past. Such a system will be needed in such fields as archeology and art history. The technique is ideal for use in deep machine learning technologies. To carry out the reconstruction of a specific work, the main aspects are considered: origin, development, principles of classical painting, technology, influence on other types of fine art (philosophy, utilitarian application, subject matter). The research methodology is based on the use of historical, cultural, art history and biographical approaches.

Keywords: Reconstruction; Ancient Greek painting; Encaustics; Cameo; Drawing; Composition; Culture; Artistic task; Machine learning 


\section{INTRODUCTION}

With the development of information technology, the subject of research data is gaining practical application for the creation of specialized databases and applications based on neural networks. To date, the problem of reconstruction is little covered in the modern scientific literature. Although all the necessary technical means are already available. Of course, this is a difficult job but absolutely necessary for a fuller understanding of the ancient past. In our opinion, the possibility of reconstructing drawings and compositions is based on the tradition of the ancient Greeks, to make countless copies of famous paintings in various techniques, because painting was valued above other arts. Descriptions of modern poets and historians, copies made in other techniques can help in the search for the composition of the lost pictorial original. The reliefs are of special value because they most adequately reflect the location of minor figures and details. The most notable reliefs in ancient Greek painting are cameos, which were not accidentally called "stone painting". Every known work has been reproduced not only in copies but also in interpretations.

\section{LITERATURE REWIEW}

On this topic, we can find comments in the work of a prominent Russian specialist in the field of ancient culture Neverov O. Y. "Ancient cameos in the collection of the Hermitage" where the author unequivocally notes the possibility of using cameos for the reconstruction of ancient works. This topic is absent in modern publications. Neverov O. Y. and his team even selected several cameos - candidates suitable in his opinion for the reconstruction of famous antique compositions. Unfortunately, the work was not completed for severala number of reasons. One of them, without a doubt, was the lack of an appropriate technical base at that time.

From our point of view, one of the most informative sources on this topic is the work of Pliny the Elder. His testimony is extremely important for reconstruction, since Pliny saw with his own eyes many of the works he described. From Natural History, we learn about the first outstanding draftsman of ancient Greece, who took the painting to a new level with his vast theoretical knowledge. Pliny mentions two art theorists, Antigonus and Xenocrates, who left behind treatises on painting, which confirms the presence in $\mathrm{V}$ a. C. painting theory. Greek epigrams that describe works of art and their creators, demonstrating the highest skill of the artist. So, thanks to Pliny's information, we know that the first outstanding teacher of ancient Greece, who influenced the mass study of painting, was Pamphilus from Macedonia, and his students Apelles and Pausius became a legend of ancient painting. According to Pliny, a contemporary of Apelles, Aristides of Thebes "... was the very first who began to express in painting the temper and convey the feelings of a person, ... as well as mental confusion, somewhat harsh in colors." [3, [19.98] Pliny's seemingly insignificant remark about the coloristic features of Aristide's painting actually suggests that the Hellenistic artist conveyed the emotional instability of his characters not only by means of linear composition and drawing, but also by means of color harmony and color composition. Thus, the intensity of color combinations intensified the impression of the tension of psychological states.

In addition, a very important source of information is the works of Elian, in particular, "Colorful stories" and "Epigrams." Elian writes about "... that in Thebes the law prescribes masters, painters, and sculptors to give what they depict, features that are more elevated in comparison with reality. For understating the merits of what served as a model for a statue or painting, painters and sculptors were threatened with a monetary fine." The system of courts and fines occupied a significant place in the ancient world, exerting a great influence on the processes in society

\section{THE PURPOSE}

Form an algorithm of the scheme of actions based onon the basis of the received historical information allowing to make the reconstruction of the lost compositions of easel painting of outstanding masters of Ancient Greece.

This technique can be useful when creating computer software designed to recreate lost works of the past. A similar system will be needed in archeology and art history. The technique is ideal for use in deep machine learning technologies. To carry out the reconstruction of a specific work, the main aspects are considered: origin, development, principles of classical painting, technology, influence on other types of fine art (philosophy, utilitarian application, subject matter). The research methodology is based on the use of historical, cultural, art history, and biographical approaches. 


\section{MAIN}

The classical European painting technique of the modern era is based on ancient Greek technology. This is an indisputable factIt still hides many mysteries, and it is a blank spot on the art history map. Roman painting, which came to us from the cities of Pompeii and Herculaneum buried under the ashes, is not an example of the illustrious Greek art of the fourth century BC, in both technological and artistic aspects. Pliny the Elder wrote in the 1st century AD that the oncegreatonce great art of painting, at one time, was already fading away [3, [19.82], and there was no artist who could restore the masterpiece of Apelles "Aphrodite Anadiomene". The masterpieces of Hellenistic Greek painting were distinguished by hyperrealism thanks to the invention of Apollodorus: - modeling of shades, and also thanks to the invention of Pausius of Sikion - layer-bylayer painting, a technique that became the basis of European academic painting. Reconstruction of ancient Greek painting is the most important task of the modern school of fine arts.

The associative European painting technique of the modern era is based on ancient Greek technology. This is an indisputable fact. Despite this, it still hides many mysteries, and it is a blank spot on the art history map. Roman painting, which came to us from the cities of Pompeii and Herculaneum buried under the ashes, is not an example of the illustrious Greek art of the fourth century BC, in both technological and artistic aspects. Pliny the Elder wrote in the 1st century $A D$ that the once great art of painting, at one time, was already fading away [3, 82], and there was no artist who could restore the masterpiece of Apelles "Aphrodite Anadiomene". The masterpieces of Hellenistic Greek painting were distinguished by hyperrealism thanks to the invention of Apollodorus: - modeling of shades, and also thanks to the invention of Pausius of Sikion - layer-bylayer painting, a technique that became the basis of European academic painting. Reconstruction of ancient Greek painting is the most important task of the modern school of fine arts. Pliny identifies three stages in the development of Greek painting, in the first of which it was linear, in the second it was monochrome, and in the third "a more skillful one was invented, and such painting continues to exist even now." Even the name of the artist, Philokles from Egypt, who, according to Pliny, invented linear painting, points to the unconditional influence of Egyptian traditions.
The origin and development of ancient Greek painting took place in two centers: Sicyon and Corinth. It is these cities that are repeatedly mentioned in the "Natural History" in connection with the invention of the painting by the Greeks, the development of its linear form, the first application of paint "from crushed tiles" [3, [19.81]. Also, the author of "Natural History" makes the necessary clarification that "only those artists who painted pictures on boards have fame" [19.118], which distinguishes easel painting as the main one in ancient Greek culture. Apollodorus Apolodor invents the black and white modeling (last third of the 5th century BC). Pliny mentions two art theorists, Antigonus and Xenocrates, who left behind treatises on painting, which confirms the presence in $\mathrm{V}$ a. C. painting theory. Greek epigrams that describe works of art and their creators that demonstrate the highest skill of the artist. Combining a scientist and an artist, Apelles was not only a master of realistic light and shadow modeling of forms, but also a master of movement composition. He became famous for the painting "Aphrodite Anadiomene", depicting the goddess of love, emerging from the sea foam.

The popularity of this work prompted other artists to reproduce it in sculpture, an example of which, in a Roman copy, has survived to this day. It is also remarkable that for the final quality of a painting, not only aspects such as composition, drawing, technology, formal techniques, color harmony were important, but also the art of varnishing the work. Pliny writes that Apelles had no equal in this art. [3, [19.97]. The innovation of Pausius was the depiction of the object in a strong foreshortening, which testifies to the highest skill of the drawing. In the large painting "The Sacrifice of Bulls", "wishing to show the length of the bull, he painted it facing from the front, not from the side ..." [3, [19.104]. The most remarkable invention of Pausius was a fundamentally new method of creating a painting, consisting in the layer-by-layer principle of applying local color and light. Thus, Pausia of Sikion can be considered the creator of the technology of classical painting. It must be said about the palette of colors used by the ancient Greeks to achieve the incredible heights of art, which history testifies. There were only four of these colors: white (Melian), ocher (Attic), red (Pontic Sinop), and black (atrament). The issue of reconstruction of the original hot encaustic technology remains open until recently. The author of the book "Antique Cameos in the 
Hermitage Collection" and the compiler of the catalog O. Y. Neverov wrote: "Of all the aspects of studying ancient cameos, perhaps the most curious and promising is the question of their relation to antique easel painting." Layered sardonyx reproduced the effect of layered classical painting, and the translucency and coloristic saturation of the stone resembled encaustic. "Along with Pompeian frescoes, reliefs, and toreutics, cameos are indispensable in the reconstruction of the forever lost easel works of ancient painters. When the same composition is repeated without changes in a fresco, decorative relief, on a silver or bronze vessel, lamp and cameo, it can be unmistakably assumed that these repetitions are based on a painterly original.

\section{RECONSTRUCTION STAGES}

The reconstruction of a painting consists of such stages as:

1. Reconstruction of the composition;

2. Reconstruction of the drawing;

3. Reconstruction of the painting system.
Reconstruction of a the composition consists of such stages as:

1. Research of surviving artifacts and selection of the most repeated compositional techniques;

2.Clarification of such elements of the composition as:

a) format;

b) the height of the horizon line;

c) minor figures and details.

Reconstruction of a drawing consists of such stages as:

1) Compilation of extant artifacts that match the descriptions of ancient authors.

2) Reconstruction of the drawing based on the resulting image.

Painting reconstruction consists of such stages as:

1) Determination of the coloristic solution based on antique samples;

2) Creation of a project of layered classical painting with fixation of all intermediate layers.

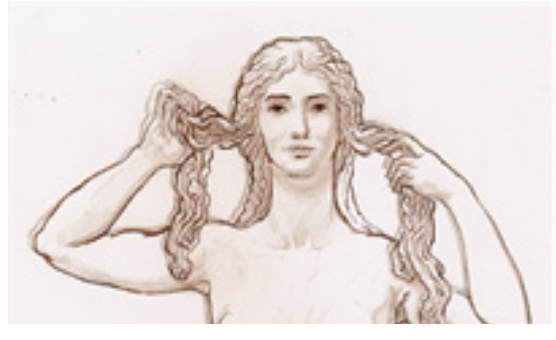

a). Drawing.

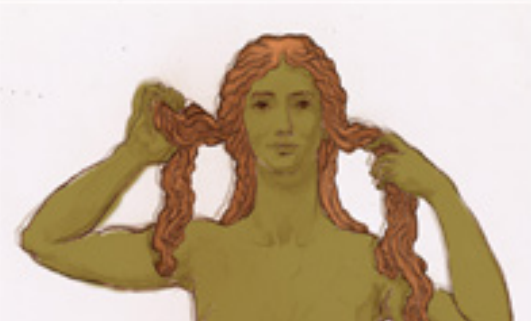

b). Middle tone.

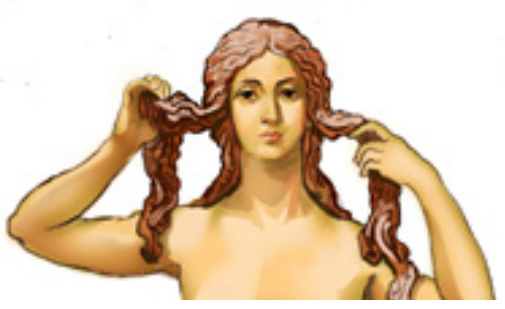

c). Volumemetric model

Figure 1. The scheme of the stages of work in the reconstruction of the figure of Aphrodite Apelles (Developed by the authors)

An example is the unusual work of Apelles: "Aphrodite Anadiomene." Here we see a methodology that, from our point of view, allows us to reconstruct the image of the goddess. We are practically convinced of the main figure. The most numerous descriptions, copies, and interpretations refer to the image of Aphrodite Anadiomene. Two sculptural copies that match the epigrams and descriptions of Pliny the Elder: "Aphrodite Cyprene", who returned to Libya in 2008, and "Aphrodite Anadiomene", located in the National Museum of Rome. E. Rothenberg wrote about the statue of Aphrodite of Cyrene: The statue depicted Aphrodite emerging from the water and squeezing wet hair, as depicted in the famous painting of the great Greek artist Apelles. Unfortunately, the head and arms of the statue did not survive [216, 275]. The most informative copy is "Aphrodite Anadiomene" from the National Museum of Rome, because she not only held her hands, but also her curled hair. The head of Aphrodite has been preserved in the interpretation of "Aphrodite of Rhodes", as well as in the form of numerous figurines. When refining the portrait of "Aphrodite Anadomena" by Apelles, one should pay attention to Praxiteles' sculpture "Aphrodite of Cnidus", which undoubtedly depicts a portrait of Phryne, who inspired Apelles and Praxiteles, famous friends, to create masterpieces. painting and sculpture. It is known that Protogen wrote an essay in two volumes "On the art of painting and schemes" [3]. The academic school of drawing, composition, and color harmony, dating 
back to its ancient origins, was based on schematics designed by prominent artists and sculptors of ancient Greece. The "limited palette" of ancient Greek artists consisted of only four colors, which made it possible to create a harmonious, rich, and refined painting. We can systematize four colors (red, yellow, white, and black) in a square of colors (Fig. 2).

Such a color harmony scheme could be in Protogen's treatise. The square of colors (Fig.2) of ancient Greek painting is a simple and understandable scheme for the harmonious combination of nuances of complementary colors. Unlike Goethe's color wheel, which includes two spectral color triads without black, the Color Square (Fig. 2) contains the basic information needed for classical painting, which cannot exist without black paint. The square of flowers (Fig. 2) is intended for artists, taking into account the specific requirements of classical painting, and consists of 25 squares. The corner squares are in the primary colors. The black color of the Square of Flowers (Fig. 2) is located in the lower right corner and performs the same function as the blue color of the Goethe Color Wheel or Otto Runge's Color Sphere, but with a quality result that is more harmonious for classical painting. Black paint mixed with white paint in varying proportions produces blue-gray shades.

The application of layers of white paint over gray imprimature gives a bluish tint. White is in the lower-leftlower left corner. Red is in the top left corner. The yellow color of the Square of Flowers (fig. 2). is in the upper right corner. Three transition tones connect each of the four colors with its neighbor. The transitional tones of complementary colors are conveniently located opposite each other along the vertical and horizontal axes. A remarkable characteristic of the Square of Colors (Fig. 2) is that additional pairs of face shades are already in a different tonal state, which is necessary for their harmonious combination. The transition from yellow to white and from red to black is carried out diagonally. On the diagonal axes, harmonious chords of contrasting color nuances are also found. We know four primary colors and intermediate tones. Thanks to the technology of Byzantine iconography, we have an idea of how the ancient Greeks used layers of paint and what types of mixtures. And eventually, we can intuitively understand how it works.

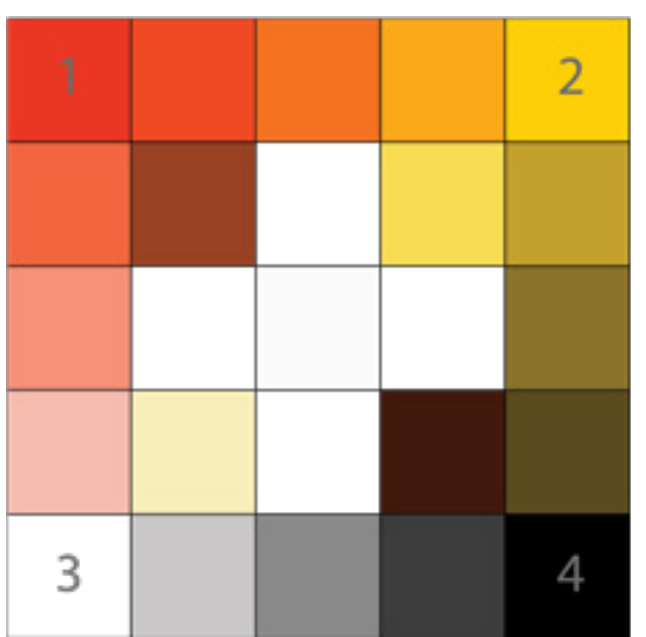

Figure 2. Scheme color square. (Developed by the authors)

This is because there are certain artistic rules that justify the use of light and shadow depending on the lighting and pose of the model:

1. After the drawing was completed (fig.1a), Apelles had to draw the silhouette of the figure in olive tone (fig.1b). The reason for this layer is to create a mid-tonemid tone that will simulate midtones between highlights and shadows. The hair is colored brown (Fig. 1b).

2. The next step is to cover the surface of the body with a flesh tone slightly lighter than the previous layer. In the case of lighter brown hair (Fig. 1c).

3. With the same flesh color, but slightly lighter, more illuminated areas stand out. This procedure is repeated three times with less and less occupied area. And at the end of everything, small strokes of almost white color are placed (Fig. 1c).

4. Then the reddish parts of the body, for example, on the cheeks, are painted with transparent red ocher. The work is then combined with a very transparent layer of yellow ocher, and the shadows with a dark brown transparent (Fig. 1c).

Unfortunately, historiographers of the past have left us no mention of the size and proportion of the work. We can only draw conclusions based on secondary information. We can assume that Apelles' painting was of considerable size. Most likely - the height of a person. This hypothesis is supported by many stories commented by the Roman historians themselves. We have the words of a historiographer how charming Aphrodite Apelles was. In the art world, there is an ancient aesthetic rule according to which a human figure cannot be life-size, it must be slightly larger or 
smaller. Thus, the Greeks had to follow this. We get a working height of $1.70-1.60 \mathrm{~m}$. Following Pliny's words at that moment, the Goddess emerges from the sea. Logically, the format for a standing figure will be vertical.

Currently, two techniques of ancient Greek painting are known - tempera and encaustic. The most important works that the Greek craftsmen created were performed in a more advanced and significant technique - encaustic. This is a technique where the base of the colorful paste is beeswax. Even Pliny does not comment on the technique directly used in the painting. But he mentions that he saw the work in person. About 400 years have passed since its creation. The painting was exhibited in the open air according to the Hellenistic tradition. It is also noted that the bottom edge of the board has already been worn out. But not a picture. All indications are that Aphrodite was painted using this magnificent technique, which has great resistance to corrosion. This is due to the material used. The Greeks secretly used special mixtures of refined wax "Punic wax" with other ingredients. Some cleaning recipes can be found in the works of Pliny himself.

We can see different ways of using the same material. Some are rough and full of cautery marks, but some appear very even and smooth. It can be assumed that one of the most famous works of history was made in athe second way. Thus, there was no way for Apelles to create a stretch of color in one encaustic layer. This is due to the form of application. For this reason, the Greeks developed a very specific technique that solved this problem for both techniques. Thus, we have almost all the pieces of this puzzle.

\section{RESULTS AND DISCUSSIONS}

On the example of the author's research given in this article, we can get an idea of the importance of various types of information sources for the reconstruction of lost works. They can be conditionally divided into groups.

1. Literary sources - descriptions of contemporaries.

2. Artifacts - contemporaries of the lost work, which are a kind of copies repeating the composition of the lost work: cameos, ceramics, sculptures, coins.

3. The technology for creating a specific work.

4. Indirect historical facts to help complete the picture. The main points necessary for the restoration of the lost pictorial work of art have been established. The basic algorithm of reconstruction is stated: drawing, composition, and methodology of the work of ancient Greek art. The Hellenistic Greek colouristics is systematized according to the "Color square" scheme. All this information used in deep machine learning technologies according to certain algorithms can give very interesting results.

\section{CONCLUSIONS}

Established the basic necessary items for the restoration of the lost pictorial works of art. The basic reconstruction algorithm is described: the drawing, composition, and methodology of the work of ancient Greek art. Systematized Hellenistic Greek colors according to the scheme "Colored Square". A sequence has been developed for the reconstruction of the main figure of Apelles' work: "Aphrodite Anadiomena". This technique can be useful when creating computer software designed to recreate lost works of the past. A similar system will be needed in archeology and art history. The technique is ideal for use in deep machine learning technologies (Fig. 3).

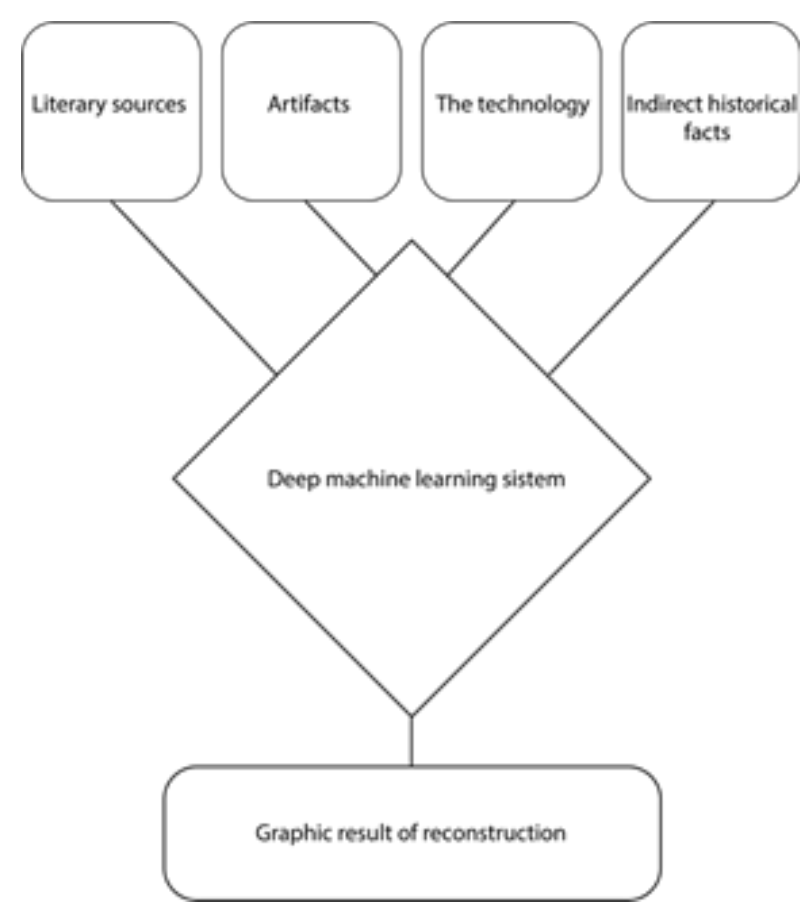

Figure 3. Scheme of algorithm (Developed by the authors) technologies. Theory and practice of design. 1(22). C.79-87, doi: 10.18372/2415-8151.22.15396 


\section{REFERENCES}

[1] Arydas A., Devetzi A., Birtacha K. (2010). Lead pigments and related tools at Akrotiri, Thera, Greece. Provenance and applicationappli-cation techniques, $\mathrm{J}$. Archaeol. Sci., 7. 8, 1830-1840 p.

[2] Allen D. (1998). Roman Glass in Britain. Boston. Shire Publications. $64 \mathrm{p}$.

[3] Berman, Lawrence; Freed, Rita E. (2003) Arts of Ancient Egypt. Museum of Fine Arts Boston. 193 p.

[4] Bray C. (2000). Ceramics and glass: a basic technology. Society of Glass Technology, $276 p$.

[5] Brecoulaki H. (2014). Precious colours in ancient Greek painting and polychromy: Material aspects and symbolic values. Révue Archéologique 1, p. 1-36.

[6] Brill R., Rising A., Stapleton P. (1999). Chemical analyses of early glasses. Corning Museum of Glass, 336 p.

[7] Chandrahas M., Gupta D. L. (2017). Deep Machine Learning and Neural Networks. IAES International Journal of Artificial Intelligence (IJ-AI) Vol. 6, No. 2, p. 66-73.

[8] Chistyakova N. A. (1993). Grecheskaya epigramma. Sanct Piterburg. Nauka. 448 str. [in Russian]

[9] Duffy E. M. (1962). Philip Pargeter and John Northwood I, Cameo Glass Pioneers. Antiques, v. 82, no. 6, p. 639. -641 .

[10] Eliano C. Bevegni C. (Traduttore) (1996). Storie varie. Adelphi. p. 321.

[11] Flinders Petrie, W.M. (1911). 91 Roman Portraits in Egypt. Man 11. p. 145-47.

[12] Ge Wang, Jong Chu Ye, Klaus Mueller, Jeffrey A. Fessler. (2018). Image Reconstruction is a New Frontier of Machine Learning. IEEE Transactions on Medical Imaging. Vol. 37, Is. 6, p. 1289 - 1296.

[13] Goethe W. (1970). Theory of Colours. MIT Press Ltd. p. 468.

[14] Itten I. (1974). The Art of color. John Wiley \& Sons. p. 160.

[15] Keuls E. (1975). Skiagraphia Once Again. Journal of Archaeology (79) 1. p. 1-16.

[16] Lydakis S. (2004). Ancient Greek Painting and Its Echoes in Later Art. Oxford University Press. $p$. 320..

[17] Mairs R., Stevenson A. (2007). Egyptian artifactsartefacts from Central and South Asia. p. 74-89.

[18] Neverov O. Y. (1988). Antichnyye kamei $v$ sobranii Ermitazha. Illyustrirovannyy katalog. Iskusstvo, 225 c. [in Russian]

[19] Pliny the Elder; William P. Thayer (contributor). (2009). Pliny the Elder: the Natural History (Latin and English). University of Chicago. vol. 35., p. 1-202.

[20] Prag, A. (2002). Proportion and personality in the Fayum Portraits. Bmsaes n. 3, 55-63.

[21] Rotenbrg E. I. (1963). Vseobshchaya istoriya iskusstv. T.1 Istoriya drevnego mira. Gosudarstvennoye izdatel'stvo «Iskusstvo». Moskva. c. 924. [in Russian]

[22] Schmid H. (1926). Enkaustik und Fresko auf antiker Grundlage. Callwey. p. 102.

\section{ЛITEPATУРA}

[1] Arydas A., Devetzi A., Birtacha K. (2010). Lead pigments and related tools at Akrotiri, Thera, Greece. Provenance and applicationappli-cation techniques, J. Archaeol. Sci., 7. 8, 1830-1840 p.

[2] Allen D. (1998). Roman Glass in Britain. Boston. Shire Publications. $64 \mathrm{p}$.

[3] Berman, Lawrence; Freed, Rita E. (2003) Arts of Ancient Egypt.. Museum of Fine Arts Boston. 193 p.

[4] Bray C. (2000). Ceramics and glass: a basic technology. Society of Glass Technology, $276 p$.

[5] Brecoulaki H. (2014). Precious colours in ancient Greek painting and polychromy: Material aspects and symbolic values. Révue Archéologique 1, p. 1-36.

[6] Brill R., Rising A., Stapleton P. (1999). Chemical analyses of early glasses. Corning Museum of Glass, $336 p$.

[7] Chandrahas M., Gupta D. L. (2017). Deep Machine Learning and Neural Networks. IAES International Journal of Artificial Intelligence (IJ-AI) Vol. 6, No. 2, p. 66-73.

[8] Чистякова Н. А. (1993). Греческая эпиграмма. Санкт Петербург. Наука. 448 с. .

[9] Duffy E. M. (1962). Philip Pargeter and John Northwood I, Cameo Glass Pioneers. Antiques, v. 82, no. 6, p. 639. -641 .

[10] Eliano C. Bevegni C. (Traduttore) (1996). Storie varie. Adelphi. p. 321.

[11] Flinders Petrie, W.M. (1911). 91 Roman Portraits in Egypt. Man 11. p. 145-47.

[12] Ge Wang, Jong Chu Ye, Klaus Mueller, Jeffrey A. Fessler. (2018). Image Reconstruction is a New Frontier of Machine Learning. IEEE Transactions on Medical Imaging. Vol. 37, Is. 6, p. 1289 - 1296.

[13] Goethe W. (1970). Theory of Colours. MIT Press Ltd. p. 468.

[14] Itten I. (1974). The Art of color. John Wiley \& Sons. p. 160.

[15] Keuls E. (1975). Skiagraphia Once Again. Journal of Archaeology (79) 1. p. 1-16.

[16] Lydakis S. (2004). Ancient Greek Painting and Its Echoes in Later Art. Oxford University Press. $p$. 320.

[17] Mairs R., Stevenson A. (2007). Egyptian artifactsartefacts from Central and South Asia. p. 74-89.

[18] Неверов О. Ю. (1988). Античные камеи в собрании Эрмитажа. Иллюстрированный каталог. Искусство, 225 с.

[19] Pliny the Elder; William P. Thayer (contributor). (2009). Pliny the Elder: the Natural History (Latin and English). University of Chicago. vol. 35., p. 1-202.

[20] Prag, A. (2002). Proportion and personality in the Fayum Portraits. Bmsaes n. 3, 55-63.

[21] Ротенберг Е. И. (1963). Всеобщая история искусств. Т. 1 История древнего мира. Государственное издательство «Искусство». Москва. с. 924

[22] Schmid H. (1926). Enkaustik und Fresko auf antiker Grundlage. Callwey. p. 102. 


\section{АНОТАЦІЯ}

Петрушевський А.О., Петрушевська Н.I. Реконструкція давньогрецького живопису в контексті сучасних цифрових технологій

Досліджується можливість формування алгоритму, що дозволяє реконструювати втрачені твори станкового живопису видатних майстрів Античного світу.

Мета. Сформувати алгоритм дій на основі отриманої історичної інформації, що дозволяє зробити реконструкцію втрачених творів станкового живопису видатних майстрів Давньої Греції.

Методологія. У дослідженні використано наступні методи:

1) аналітичний метод, за допомогою якого була проаналізована література;

2) теоретико-концептуальний метод, який дав змогу визначити умови, необхідні для впровадження IT-технології в культурномистецьку практику;

У дослідженні використовувались методи комп'ютерного моделювання та аналізу, що дозволило підвищити точність результатів. Автори статті послідовно розглядають алгоритм дій, необхідних для відновлення втрачених творів минулого. Робота враховує технологічні особливості пошарового розпису Стародавнього світу та аналізує колірну гамму, яку використовували майстри античності. Для наочності автори створили спеціальну схему - кольоровий квадрат. Створення цього матеріалу передувало глибоке вивчення античних джерел, зокрема праць Плінія Старшого.

Результати. Встановлено основні моменти, необхідні для відновлення втраченого живописного твору мистецтва. Викладено основний алгоритм реконструкції: малюнока, композиції та методології. створення твору Античного мистецтва. Елліністична грецька колористика систематизована за схемою «Кольорового квадрата». Вся ця інформація, може бути використана в технологіях глибокого машинного навчання за певними алгоритмами i, може дати дуже цікаві результати.

Наукова новизна. Полягає у створенні схеми дій, спрямованої на відновлення зображення, максимально наближеного до загубленого оригіналу на основі збережених літературних джерел та матеріальних артефактів.

Практична значущість. Цей алгоритм може бути корисним при створенні комп'ютерно-

\section{АННОТАЦИЯ}

Петрушевский А.А., Петрушевская Н.И. Реконструкция древнегреческой живописи в контексте современных цифровых технологий.

Исследуется возможность формирования алгоритма, позволяющего реконструировать утраченные произведения станковой живописи выдающихся мастеров античного мира.

Цель. Сформировать алгоритм действий на основе полученной исторической информации, позволяющей сделать реконструкцию утраченных произведений станковой живописи выдающихся мастеров Древней Греции.

Методология. В исследовании использованы следующие методы:

1) аналитический метод, с помощью которого была проанализирована литература;

2) теоретико-концептуальный метод, который позволил определить условия, необходимые для внедрения IT-технологии в культурно-художественную практику;

В исследовании использовались методы компьютерного моделирования и анализа, что позволило повысить точность результатов. Авторы статьи последовательно рассматривают алгоритм действий, необходимых для восстановления утраченных произведений прошлого. Работа учитывает технологические особенности послойного росписи Древнего мира и анализирует цветовую гамму, которую использовали мастера античности. Для наглядности авторы создали специальную схему - цветной квадрат. Создание этого материала предшествовало глубокое изучение античных источников, в том числе работ Плиния Старшего.

Результаты. Установлены основные моменты, необходимые для восстановления утраченного живописного произведения искусства. Изложено основное алгоритм реконструкции: рисунок, композиция и методологии. создание произведения античного искусства. Эллинистическая греческая колористика систематизирована по схеме «Цветного квадрата». Вся эта информация может быть использована в технологиях глубокого машинного обучения по определенным алгоритмам и, может дать очень интересные результаты.

Научная новизна. Заключается в создании схемы действий, направленной на восстановление изображения, максимально приближенного к потерянному оригинала на основе сохранившихся литературных источников и материальных артефактов.

Практическая значимость. Этот алгоритм может быть полезным при создании компьютерного программного обеспечения, пред-

(C) Petrushevskyi A., Petrushevska N. (2021). Reconstruction of ancient greek painting in the context of modern digital technologies. Theory and practice of design. 1(22). C.79-87, doi: 10.18372/2415-8151.22.15396 
го програмного забезпечення, призначеного для відтворення втрачених творів минулого. Подібна система буде потрібна в таких галузях як археологія та історія мистецтва. Методика ідеально підходить для використання в технологіях глибокого машинного навчання. Для проведення реконструкції конкретного твору розглядаються основні аспекти: походження, розвиток, принципи класичного живопису, технологія, вплив на інші види образотворчого мистецтва (філософія, утилітарне застосування, тематика). Методологія дослідження базується на використанні історичного, культурного, мистецтвознавчого та біографічного підходів.

Ключові слова:

реконструкція; давньогрецький живопис; енкаустика; камея; малюнок; композиція; культура; художнє завдання; машинне навчання. назначенного для воссоздания утраченных произведений прошлого. Подобная система будет нужна в таких отраслях как археология и история искусства. Методика идеально подходит для использования в технологиях глубокого машинного обучения. Для проведения реконструкции конкретного произведения рассматриваются основные аспекты: происхождение, развитие, принципы классической живописи, технология, влияние на другие виды изобразительного искусства (философия, утилитарное применение, тематика). Методология исследования базируется на использовании исторического, культурного, искусствоведческого и биографического подходов.

Ключевые слова: реконструкция; древнегреческая живопись; энкаустика; камея; рисунок; композиция; культура; художественная задача; машинное обучение.

\section{AUTHOR`S NOTE}

\author{
Петрушевський Андрій Олександрович \\ - кандидат технічних наук, доцент кафедри \\ інформаційних технологій та дизайну \\ Державного університету інфраструктури $і$ \\ технологій, м.Київ, Україна, \\ e-mail: zmodeller@gmail.com, \\ orcid: 0000-0002-4199-2179
}

Петрушевська Наталія Ігорівна - м. Київ, Україна,

e-mail: natalipetrushevski@gmail.com, orcid: 0000-0001-5542-0174 